\title{
Larvicidal Activity of Some Botanical Extracts, Commercial Insecticides and their Binary Mixtures Against the Housefly, Musca Domestica L.
}

\author{
S. A. Mansour ${ }^{*}, 1$, R. F.A. Bakr ${ }^{2}$, R. I. Mohamed ${ }^{1}$ and N.M. Hasaneen ${ }^{3}$ \\ ${ }^{I}$ Environmental Toxicology Research Unit (ETRU), Department of Pesticide Chemistry, National Research Centre, \\ Dokki, Cairo, Egypt \\ ${ }^{2}$ Department of Entomology, Faculty of Science, Ain Shams University, Cairo, Egypt \\ ${ }^{3}$ Department of Zoology, Faculty of Science, Sohag University, Egypt
}

\begin{abstract}
Following preliminary screening of 13 ethanolic plant extracts, belonging to 10 different families, a total of 11 extracts were subjected to detailed toxicity evaluation against the larval stage of the housefly, Musca domestica L. The larvicidal $\mathrm{LC}_{50}$ values were $<100 \mathrm{ppm}$ for Piper nigrum (50.1 ppm), Azadirachta indica $(76.9 \mathrm{ppm})$, Conyza aegyptiaca $(77.0 \mathrm{ppm})$ and Cichorium intybus $(96.8 \mathrm{ppm})$; representing the highest potent extracts among the bioassayed candidates. Punica granatum extract exhibited the lowest toxicity (213.9 ppm). In comparison, commercial insecticides showed superior larvicidal toxicity; accounting to the following $\mathrm{LC}_{50}$ values: $0.029,0.03,0.61$ and $0.64 \mathrm{ppm}$ for deltamethrin, methomyl, chlorpyrifos and flufenoxuron, respectively. Combining botanical extracts with insecticides, at equitoxic dosages (e.g., $\mathrm{LC}_{25}$ values), induced potentiating effects for a 44 bioassayed mixtures against the housefly larvae. Moreover, mixing the insecticides at $\mathrm{LC}_{0}$ (a concentration level causing no observed mortality) with the $\mathrm{LC}_{50}$ of each of the plant extracts have resulted in 44 paired combinations. Mostly, the "synergistic factor; S.F." ranged between 1.6 - 1.9; giving rise to high synergistic effects. Specifically, the synergistic effect was much pronounced for mixtures of the insecticide deltamethrin with different botanical extracts. Most of the tested toxicants induced different forms of developmental effects after exposure of $3^{\text {rd }}$ larval instars to sublethal concentrations $\left(\mathrm{LC}_{25} \mathrm{ppm}\right)$. Larvae treated with A. indica, Citrus aurantifolia, Eucalyptus globulus (leaves or fruits), P. granatum, Salix safsaf, Sonchus oleraceus, Zea mays, as well as the insecticides chlorpyrifos, deltamethrin and methomyl failed to develop into adult stages. Morphologically, there were different forms of pupal and adult abnormalities, where the treatments of $P$. granatum and $S$. oleraceus caused abnormal pupal size in addition to pupal-adult intermediate. In the resulted Musca domestica adults, the effects were seen as one-winged insects, small size, compressed body and abdomen elongation. Such deformations were attributed to treatments of $C$. intybus, C. aegyptiaca, Piper nigrum and the IGR flufenoxuron. The overall results of the present investigation reveal the broad-spectrum toxic properties of the tested plant extracts against Musca domestica larvae; which may encourage further research on housefly control in tropics using indigenous plants.
\end{abstract}

Keywords: Housefly, Botanical biocides, Insecticides, Toxicity, Joint action, Developmental effects.

\section{INTRODUCTION}

Musca domestica Linnaeus (Diptera: Muscidae), is a serious health threat to human beings and livestock by transmitting many infectious diseases [1]. It acts as important mechanical carriers of pathogenic bacteria, such as Shigella sp, Vibrio cholerae, Escherichia coli, Staphylococcus aureus, and Salmonella sp. [2]. However, the immature stages have several industrial and medical applications [3-6]. Such challenging situation requires a management strategy to interfere with the insect development in order to maintain adult stage population as lower as possible through controlling larval stage population. The high cost of chemical pesticides and the environmental hazards as a result of pesticide usage have encouraged scientists to seek less hazardous and

\footnotetext{
*Address correspondence to this author at the Department of Pesticides \& Environmental Toxicology at National Research Centre, Dokki, Cairo, Egypt; Tel: (202) 33371211; Fax: (202) 33370931;

E-mails: samansour@hotmail.com; samansour2@yahoo.com
}

cheaper pesticide groups. Considerable efforts have been made to synthesize an alternative to overcome this problem. Botanical products have become more prominent in assessing current and future pest control alternatives [7]. Over the past two decades, surveys of plant families have discovered sources of new botanical insecticides, which could possibly meet some of this demand. For instance, the potential of neem products is being conducted internationally $[1,8]$ and there is a general trend these days to reduce the risk to human life [9]. Accordingly, botanical insecticides based on natural compounds from plants, are expected to be a possible alternative. They tend to have broad-spectrum activity, relative specificity in their mode of action, and easy to process and use. They also tend to be safe for animals and the environment [10].

Many plants have been reported about their potential insecticidal actions on different stages of $M$. domestica via crude extracts or extracted active compounds [11-15]. Some results also showed their effects on metamorphosis or emergence or fecundity or life span of house flies $[12,15,16]$. 
Indeed, the rational application of exceptional phytochemicals may not only lead to new IPM strategies but may inhibit the development of insect resistance to existing synthetic insecticides. Hence, the present study was undertaken to: a) test the potency of several plant extracts and some commercial insecticides against larvae of the housefly, Musca domestica, using standard test methods; b) analyze the joint action toxicity resulting from mixing botanical extracts with insecticides; c) investigate synergistic effects of botanical extracts to non-lethal concentration levels of synthetic insecticides; and d) study the effect of sub-lethal concentrations of the prepared substances on the insect development.

\section{MATERIALS AND METHODS}

\section{Test Insect}

Musca domestica (MD) house flies were reared in the insect rearing room of our laboratory at $25-27^{\circ} \mathrm{C}$, and $55-$ $60 \%$ relative humidity. A standard rearing method [17] was adopted to provide $3^{\text {rd }}$ larval instars used for running bioassay tests.

\section{Plants}

The following 12 plant species were used in the present study: Azadirachta indica, Cichorium intybus, Citrus aurantifolia, Conyza aegyptiaca, Eucalyptus globulus (fruits and leaves), Opuntia vulgaris, Piper nigrum, Punica granatum, Saccharum sp., Salix safsaf, Sonchus oleraceus, and Zea mays. The used part of each plant is shown in Table 1. Dry seeds/fruits of neem (A. indica) and black pepper ( $P$. niger) were procured from a spices supermarket, while the other plants were collected from the National Research Centre (NRC) farm. Subjected plant materials were washed, shade dried, chopped into small pieces or powdered and kept in suitable vessels until extraction.

\section{Extraction}

The method of Freedman et al., [18] was adopted with minor modification. Samples of $100 \mathrm{~g}$ plant materials were extracted in a Soxhlet apparatus, using ethanol (75\%) as solvent at a rate of $3 \mathrm{ml} / \mathrm{g}$ plant material and for $8 \mathrm{~h}$ extraction period. The solvent was evaporated to dryness under vacuum using a rotavapor with a water bath adjusted to $80^{\circ} \mathrm{C}$. The crude residues were then weighed for estimating their yield percentages (Table 1) and kept in a deep freezer $\left(-18^{\circ} \mathrm{C}\right)$ until used.

\section{Tested Insecticides}

Four insecticides were used for comparison with plant extracts. These insecticides were Deltamethrin (Decamethrin ${ }^{\circledR} ; 2.5 \%$ EC), Methomyl (Lannate ${ }^{2} ; 90 \%$ SP), Chlorpyrifos (Dursban $\AA ; 48 \%$ EC), and Flufenoxuron (Cascade $\AA ; 10 \%$ EC). These were purchased from Sidasa Company for Fertilizers, Pesticides and Chemicals, S.A.E., Cairo, Egypt.

\section{Potency of Plant Extracts and Insecticides}

Standard methods for the evaluation and testing of new insecticides [19] were followed with minor modification. Larvicidal tests were based on exposing $M$. domestica (MD) larvae to food-contaminated with toxicants (i.e., "bait"). The bait was prepared by mixing $2 \mathrm{~g}$ coarse wheat bran with $2 \mathrm{ml}$

Table 1. Plants Investigated for their Muscacidal Activities Showing Used Part, Percent Yield of Crude Extract and Percent Mortalities Against $4^{\text {th }}$ Larval Instars of Musca domestica Exposed to Definite Concentrations of Ethanolic Plant Extracts

\begin{tabular}{|c|c|c|c|c|}
\hline Plant (Family) & Used Part & Yield of Crude Extract (\%; w/w) & $\%$ Mortality at $1000 \mathrm{ppm}$ & $\%$ Mortality at $100 \mathrm{ppm}$ \\
\hline Azadirachta indica (Meliaceae) & Kernel & 25.5 & 100.0 & 87.3 \\
\hline Cichorium intybus (Asteraceae) & Whole plant & 25.0 & 100.0 & 50.0 \\
\hline Citrus aurantifolia (Rotaceae) & Fruit rind & 41.3 & 100.0 & 50.1 \\
\hline Conyza aegyptiaca (Asteraceae) & Whole plant & 25.0 & 100.0 & 80.5 \\
\hline Eucalyptus globulus (Myrtaceae) & Fruits & 29.7 & 100.0 & 40.3 \\
\hline Eucalyptus globulus (Myrtaceae) & Leaves & 49.9 & 100.0 & 49.1 \\
\hline Piper nigrum (Piperaceae) & Seeds & 10.5 & 100.0 & 100.0 \\
\hline Opuntia vulgaris (Cactaceae) & Fruit rind & 19.2 & 0.0 & 0.0 \\
\hline Punica granatum (Punicaceae) & Fruit rind & 8.0 & 100.0 & 15.7 \\
\hline Saccharum spp. (Poaceae) & Waste pulp & 25.3 & 5.5 & 0.0 \\
\hline Salix safsaf (Salicaceae) & Leaves & 30.2 & 100.0 & 20.0 \\
\hline Sonchus oleraceus (Asteraceae) & Whole plant & 17.6 & 100.0 & 50.1 \\
\hline Zea mays (Gramineae) & Leaves \& silk of ear & 15.6 & 100.0 & 19.7 \\
\hline
\end{tabular}


water containing the tested substance. Preliminary tests were carried out at 100 and $1000 \mathrm{ppm}$ to exclude extracts of no observed toxicity, especially at the higher concentration. These tests revealed excluding both Opuntia vulgaris and Saccharum spp. (Table 1). A range of concentrations (0.01 $1.0 \mathrm{ppm})$ and $(30-200 \mathrm{ppm})$ were prepared for the tested insecticides and the rest of plant extracts, respectively. Solutions of insecticides were prepared in water while those of plant extracts prepared in $0.1 \%$ ethanol solution. The latter solution was found necessary to dissolve botanical extracts. The $3^{\text {rd }}$ larval instars of MD were allowed to feed on batches of freshly prepared baits placed in $250 \mathrm{ml}$ - glass bakers; each provided with 10 larvae. Five concentrations of 4 replications each were usually tested for each studied substance along with control treatments containing bait free of plant extracts or insecticides, but supplemented with equivalent amount of ethanol. All beakers were incubated at room temperature for $24 \mathrm{~h}$, then percent mortalities were estimated and corrected according to Abbott's formula [20]. Probit analysis [21] was performed to estimate toxicity values (e.g., $\mathrm{LC}_{25}$, $\mathrm{LC}_{50}$ and $\mathrm{LC}_{95}$ ) and slope of regression line for each tested substance.

\section{Mixtures Toxicity (Joint Action)}

Paired mixtures of plant extracts with each others and with insecticides were freshly prepared at concentration levels of their respective $\mathrm{LC}_{25}$ values. Each mixture was tested in four replicates along with controls, and the tests were carried out as mentioned above. Mortality percentages were determined after $24 \mathrm{~h}$ and the combined (joint) action of the different mixtures was expressed as Co-toxicity factor according to Sun and Johnson [22] to differentiate between potentiation, antagonism and additive, using the following formula:

Co - toxicity factor $=(O-E) \times 100 / E$;

where $\mathrm{O}$ is observed \% mortality and $\mathrm{E}$ is expected \% mortality.

The co-toxicity factor differentiates the results into three categories. A positive factor of $\geq 20$ indicates potentiation, a negative factor of $\leq-20$ indicates antagonism, and the intermediate values of $>-20$ to $<20$ indicate an additive effect. Because obtained $\mathrm{LC}_{25}$ values are mathematically estimated, they were tested again against MD larvae to determine the accurate expected mortality. The expected mortality of the combined pair is the sum of the mortalities of single compounds at the given $\mathrm{LC}_{25}$ concentrations and the observed mortality is the recorded mortality obtained $24 \mathrm{~h}$ after exposure to the mixture.

\section{Synergistic/Antagonistic Action}

These tests were carried out to determine the synergistic/antagonistic action resulted from mixing a definite amount of insecticide at the concentration level causing no observed mortality $\left(\mathrm{LC}_{0}\right)$ with a plant extract at its $\mathrm{LC}_{50}$ value. By comparing moralities obtained with the expected mortality of the mixture (ca. $50 \%$ ), the resulted synergistic/ antagonistic factor (SF) could give an indication to the nature of the effect (i.e. $\mathrm{SF}>1$ means synergism; $\mathrm{SF}<1$ means antagonism; $\mathrm{SF}=1$ means no obvious effect). Each mixture was tested in four replications along with an untreated control test, according to the details mentioned above. Also, the expected mortality for the mixture was not considered as a
$50 \%$ kill, as in the original method [23]. For more accuracy, it was obtained from experimental estimation in which mortality of each single toxicant (at the $\mathrm{LC}_{0} \& \mathrm{LC}_{50}$ levels) was determined, summed and used as the expected mortality. A safety factor of \pm 0.05 was considered when ranking the synergistic/antagonistic results (i.e. no obvious effect: $\mathrm{SF}=1 \pm 0.05$, synergism: $\mathrm{SF}>1.05$, and antagonism: $\mathrm{SF}$ $<0.95)$.

\section{Developmental Studies}

The 3rd larval instars of Musca domestica were subjected to feed on the bait of coarse wheat bran prepared as mentioned above but contained the amount corresponding to the $\mathrm{LC}_{25}$ of the tested toxicants. Fifteen larvae were transferred to a- $250 \mathrm{ml}$ beaker containing the bait (ca. $2 \mathrm{~g}$ ) and 4 such beakers were prepared for each tested toxicant. The beakers were kept at room temperature and examined daily. The time required for larvae to reach pupae and adult stages was recorded. Weight and shape of the insect were also recorded throughout the experimental duration. Any abnormalities on the appearance of the different insect stages were also recorded and photographed whenever was possible. The results of treatments were compared with those of control ones in which the larvae were confined on $2 \mathrm{~g}$ of coarse wheat bran bait free of any toxicant.

\section{RESULTS}

\section{Larval Toxicity}

The results of the initial assay of extracts showed that 11 extracts induced $100 \%$ mortality of Musca domestica larvae at $1000 \mathrm{ppm}$. Other two extracts from Opuntia vulgaris and Saccharum sp. caused only 0.0 and $5.5 \%$ mortality, respectively. At $100 \mathrm{ppm}$ concentration, the toxicity ranged between $15.7 \%$ for Punica granatum to $100 \%$ for Piper nigrum extracts (Table 1).

On the basis of this result, the active plant extracts subjected to detailed investigation revealed that Piper nigrum was the most toxic $\left(\mathrm{LC}_{50}=50.1 \mathrm{ppm}\right)$ and the least active was Punica granatum extract $\left(\mathrm{LC}_{50}=213.9 \mathrm{ppm}\right)$ (Table 2). The larvicidal toxicity of the tested plant extracts, based on $\mathrm{LC}_{50}$ values suggests the following toxicity order: Piper nigrum> Azadirachta indica> Conyza aegyptiaca > Cichorium intybus > Sonchus oleraceus > Citrus aurantifolia> Eucalyptus globulus (leaves) $>$ Eucalyptus globulus (fruits) $>$ Salix safsaf $>$ Zea mays $>$ Punica granatum. At the level of $\mathrm{LC}_{95}$ values, Piper nigrum extract showed the highest larval toxicity $(105.3 \mathrm{ppm})$, and Punica granatum extract was the lowest $(278.1 \mathrm{ppm})$. The slope of regression lines ranged between 5.1 for Piper nigrum extract and 16.9 for Salix safsaf extract; indicating different degree of homogeneity or heterogeneity of the test insect against the bioassayed botanical extracts.

The insecticides were highly toxic to the housefly larvae $\left(\mathrm{LC}_{50}=0.029,0.03,0.61\right.$ and $0.64 \mathrm{ppm}$, for deltamethrin, methomyl, chlorpyrifos and flufenoxuron, respectively) and the slope values ranged between 2.1 and 5.8.

\section{Joint Action}

Combining 11 plant extracts with 4 insecticides resulted in 44 paired mixtures of different degrees of joint action to- 
Table 2. Toxicity Data for the Tested Ethanolic Plant Extracts and Insecticides Against $4^{\text {th }}$ Larval Instars of Musca domestica, as Estimated After 24 h Exposure Times

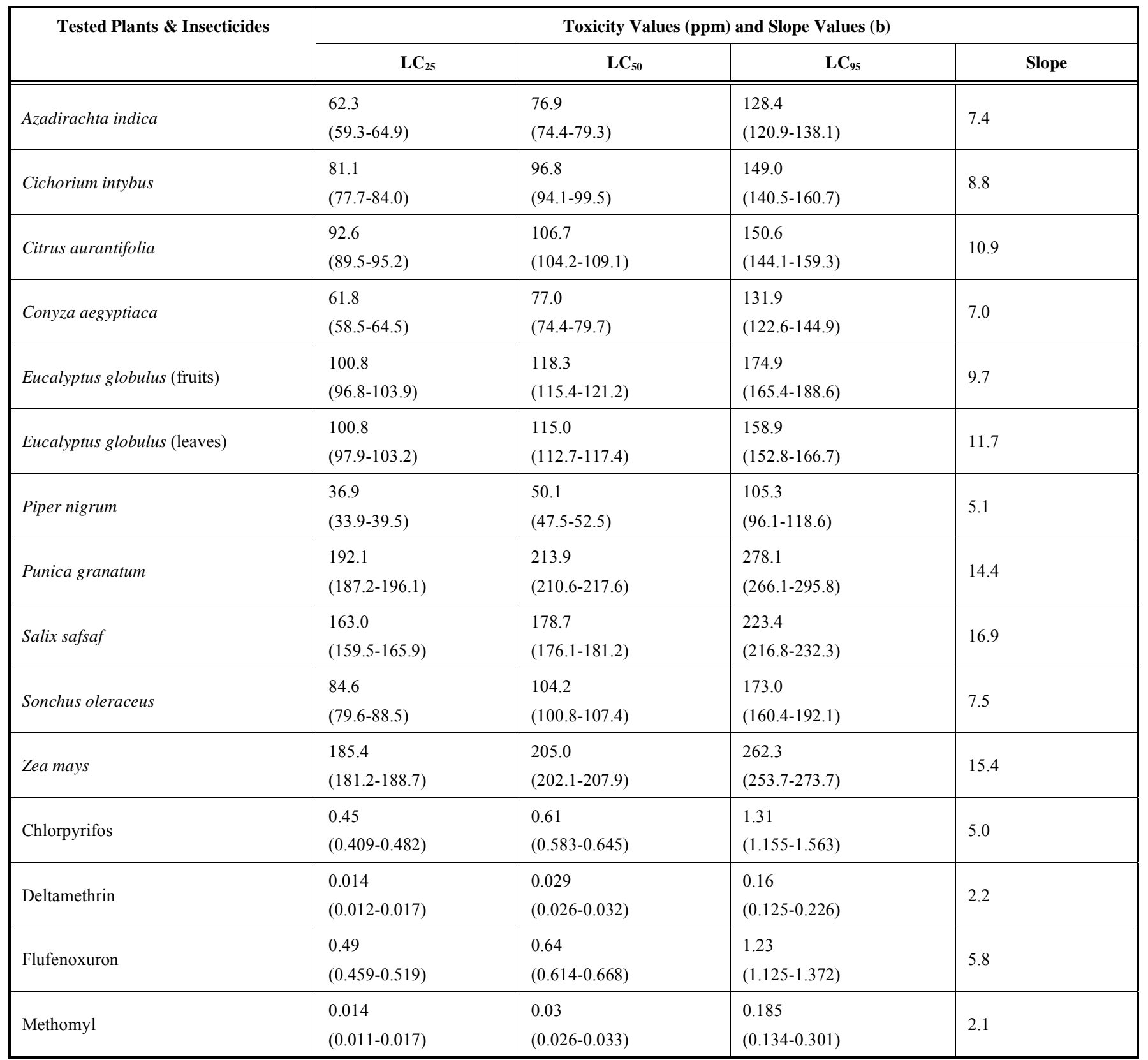

Values between brackets are $95 \%$ fudicial limits of the corresponding toxicity values. The latter values are estimated from their respective regression lines (LC-P lines).

wards larvae of Musca domestica. The calculated "cotoxicity factor" exceeded 20; a result accounting to "potentiation effect" (Table 3). The highest potentiating effect was achieved for mixtures of co-toxicity factor equaled ca 100.0 ([e.g., Cichorium intybus + methomyl; Citrus aurantifolia + chlorpyrifos; the latter insecticide with Conyza aegyptiaca, Eucalyptus globulus (fruits \& leaves), Punica granatum, Salix safsaf, Sonchus oleraceus, and Zea mays]). The lower potentiating effects were obtained for extracts such as mixtures of flufenoxuron with Citrus aurantifolia and Eucalyptus globulus (fruits \& leaves); which showed co-toxicity factors of 41.9, 34.3 and 46.0, respectively. All the tested mix- tures induced neither antagonistic nor additive effects against the tested insect (Table 3).

\section{Synergistic/Antagonistic Action}

Mixing the insecticides at $\mathrm{LC}_{0}$ (a concentration level causing no observed mortality) with the $\mathrm{LC}_{50}$ of each of the plant extracts have resulted in 44 paired combinations. Mostly, the "synergistic factor; S.F." accounted to 1.8 - 1.9; giving rise to high synergistic effects. A S.F. of 1.6, which entitled to some plant extracts (e.g., flufenoxuron with Eucalyptus globulus (leaves), Piper nigrum, and Punica granatum), was relatively considered as a result of lower synergism (Table 4). 
Table 3. Joint Action of Binary Mixtures of Botanical Extracts with Insecticides Against 4th Larval Instars of Musca domestica

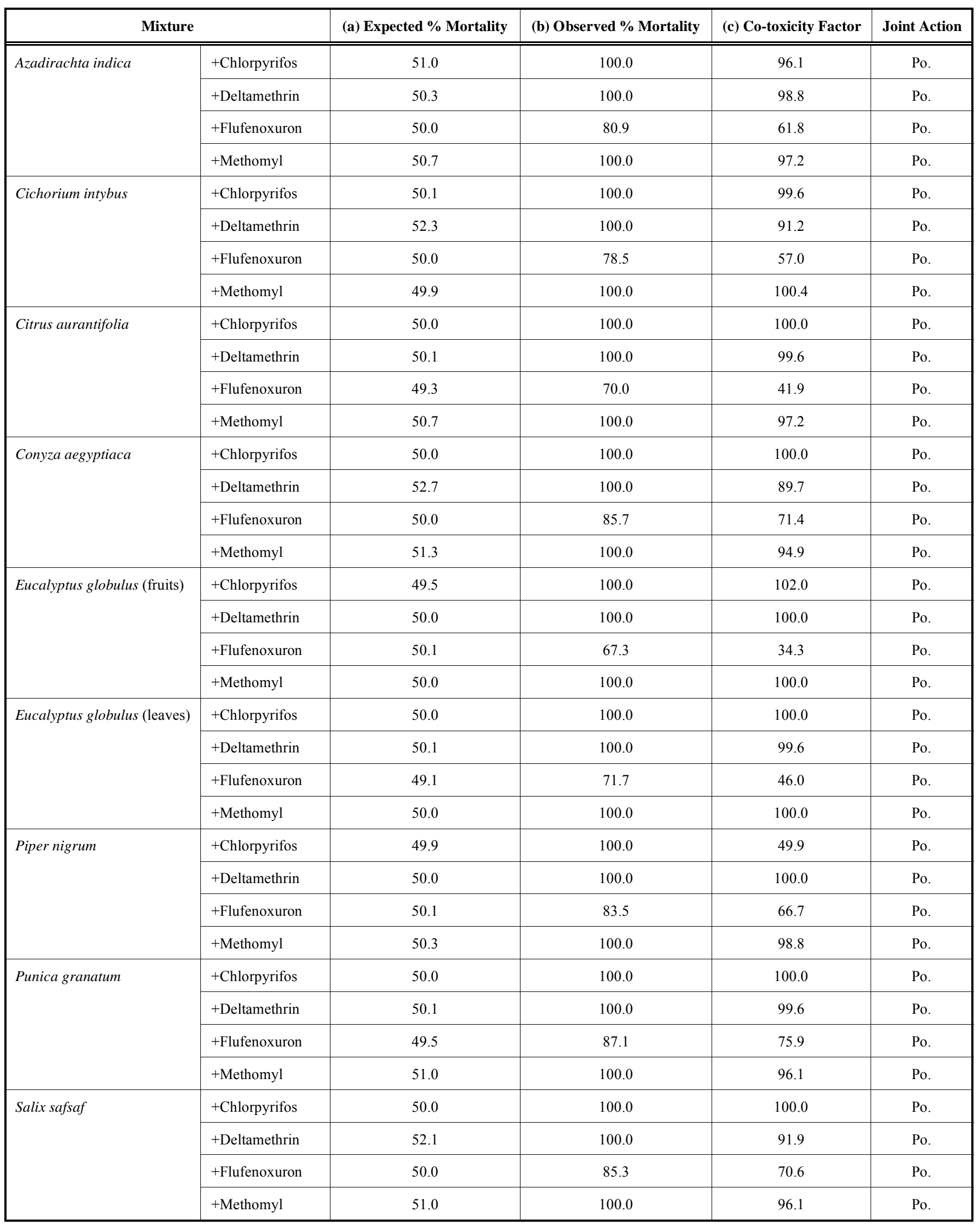


Table 3. Contd....

\begin{tabular}{|c|c|c|c|c|c|}
\hline \multicolumn{2}{|c|}{ Mixture } & \multirow{2}{*}{$\begin{array}{l}\text { (a) Expected \% Mortality } \\
50.0\end{array}$} & \multirow{2}{*}{$\begin{array}{l}\text { (b) Observed \% Mortality } \\
100.0\end{array}$} & \multirow{2}{*}{$\begin{array}{l}\text { (c) Co-toxicity Factor } \\
100.0\end{array}$} & \multirow{2}{*}{$\begin{array}{l}\text { Joint Action } \\
\text { Po. }\end{array}$} \\
\hline Sonchus oleraceus & + Chlorpyrifos & & & & \\
\hline & +Flufenoxuron & 50.0 & 90.1 & 80.2 & Po. \\
\hline & + Methomyl & 50.0 & 100.0 & 100.0 & Po. \\
\hline \multirow{3}{*}{ Zea mays } & +Deltamethrin & 50.1 & 100.0 & 99.6 & Po. \\
\hline & +Flufenoxuron & 49.7 & 90.1 & 81.3 & Po. \\
\hline & + Methomyl & 51.1 & 100.0 & 95.7 & Po. \\
\hline
\end{tabular}

${ }^{a}$ Expected mortality = summation of mortality (\%) from insects exposed to $\mathrm{LC}_{25}$ level of each toxicant in a paired combination as tested individually.

${ }^{b}$ Observed $\%$ mortality refers to that of the mixture tested in the same experimental container at the $\mathrm{LC}_{25}$ level of each.

${ }^{\mathrm{c}}$ Co-toxicity factor $=$ Observed $\%$ mortality - Expected $\%$ mortality x 100 .

Po. $=$ Potentiation

Expected \% mortality.

Table 4. Synergistic/Antagonistic Effects Resulted from Mixing Tested Insecticides and Plant Extracts at $\mathrm{LC}_{0}$ and LC $\mathrm{C}_{50}$ Concentration Levels, Respectively, as Tested Against $4^{\text {th }}$ Larval Instars of Musca domestica

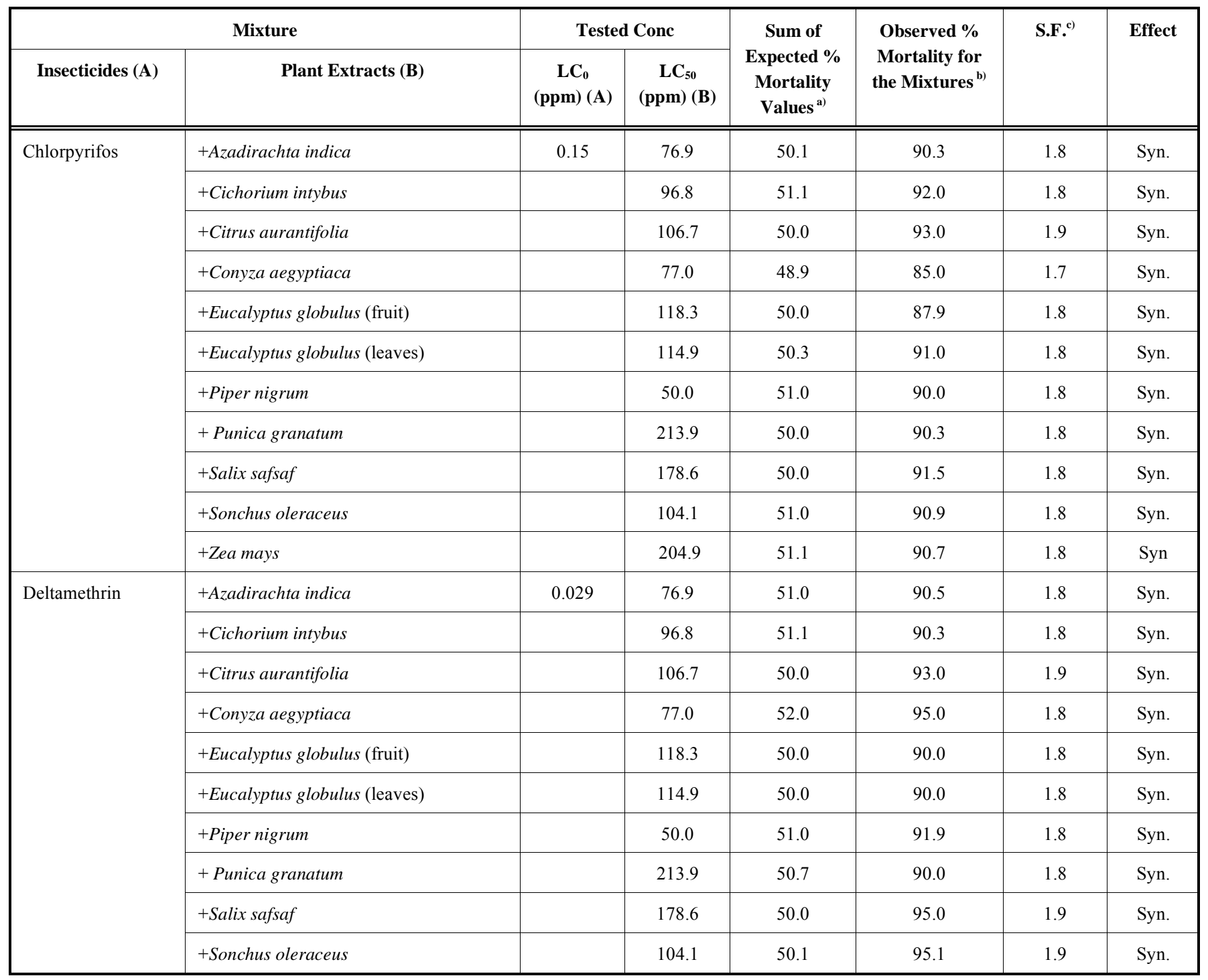


Table 4. Contd....

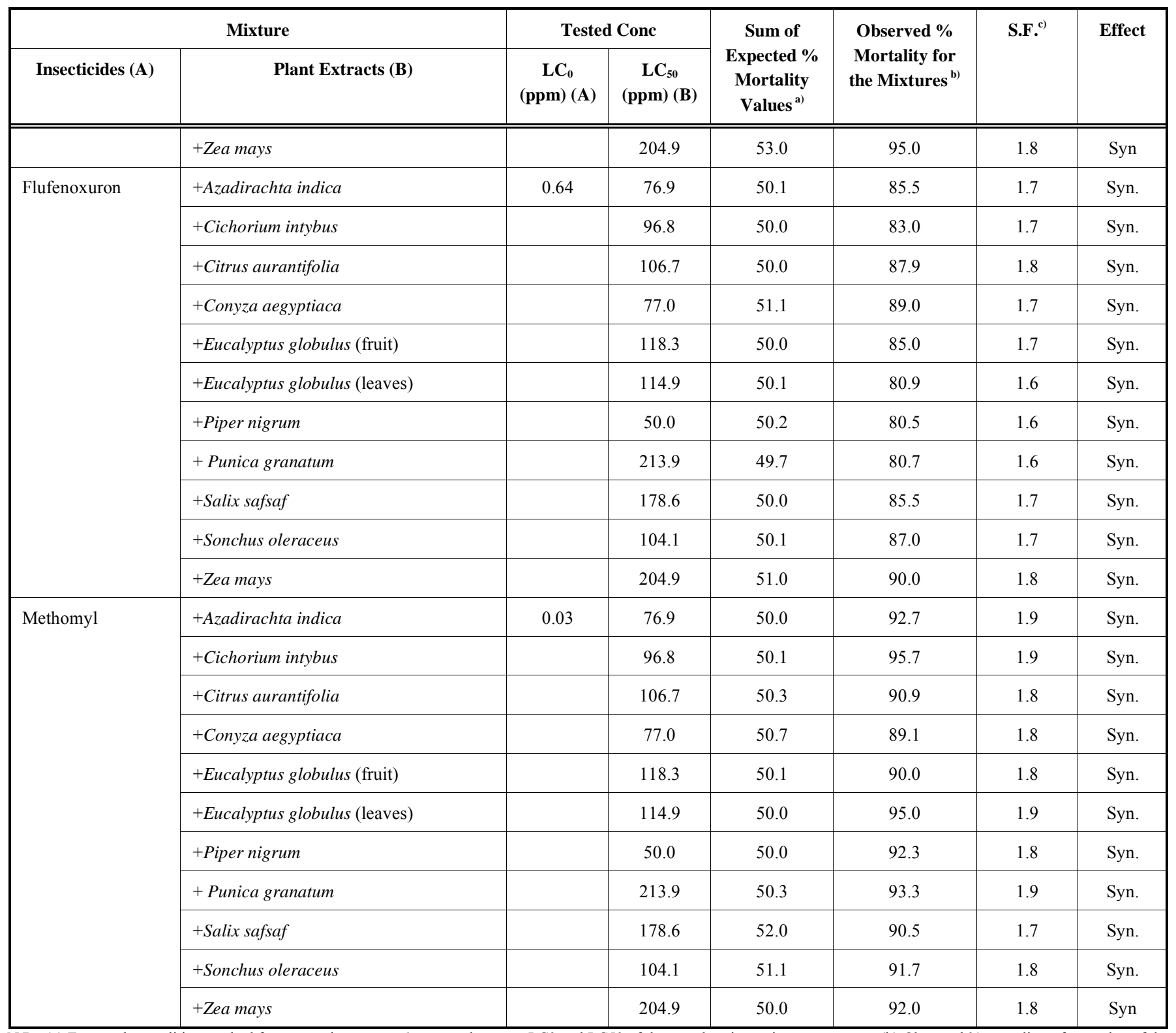

N.B.; (a) Expected mortalities resulted from exposing Musca domestica larvae to LC0 and LC50 of the tested toxicants in separate tests. (b) Observed \% mortality refers to that of the mixture tested in the same experimental container at the LC0 and LC50 levels.

(c) S.F means synergistic/antagonistic factor which resulted from dividing the observed values by practical expected values; where S.F. $=1.0 \pm 0.05$ (no effect); S.F. > 1.05 (synergism); S.F. $<0.95$ (antagonism).

Combining of different toxicants (e.g., botanicals with insecticides and insecticides together) at non-lethal concentration level of each (i.e., $\mathrm{LC}_{0}$ ), was evaluated for some paired mixtures in terms of "relative potency"; which obtained by comparing observed mortality with expected mortality as shown in Table 5. As an example demonstrating calculation of relative potency could be given for the mixture deltamethrin + Cichorium intybus. Expected mortality as explained under the Table $=0.5 \%$ and observed mortality $=$ $11.3 \%$; thus the relative potency $=11.3 \% / 0.5 \%=22.6$ folds. According to the data presented in Table 5, it clears that combination of the concerned toxicants, even at $\mathrm{LC}_{0}$ levels, induced mortality to Musca domestica larvae higher than those resulted from exposure to both toxicants individually.

\section{Developmental Effects}

The results of the tested plant extracts and insecticides on the insect development are presented in Table 6. After $24 \mathrm{~h}$ exposure period of $3^{\text {rd }}$ larval instars of Musca domestica to the tested materials, the dead larvae were removed and the survived ones were counted to ensure that the used dose induced nearly $25 \%$ mortality, and to refer the subsequent results to the actual numbers of the survived larvae. In control treatment, the average number of the tested larvae was 29.5, developed to 29.0 pupae and 24.8 adults as average numbers. Duration of these stages was accounted to 13.5, 4.5 and 20.75 days, respectively. Cumulative mortalities were accounted to $1.7 \%, 1.7 \%$ and $0.0 \%$ in larval, pupal and adult stages, respectively. Compared to the above mentioned results for control treatment, the results of the other toxicant- 
Table 5. Relative Potency of Binary Mixtures Against 4th Larval Instars of Musca domestica at Non-lethal Concentration Levels of Each Toxicant $\left(\mathrm{LC}_{0}\right)$

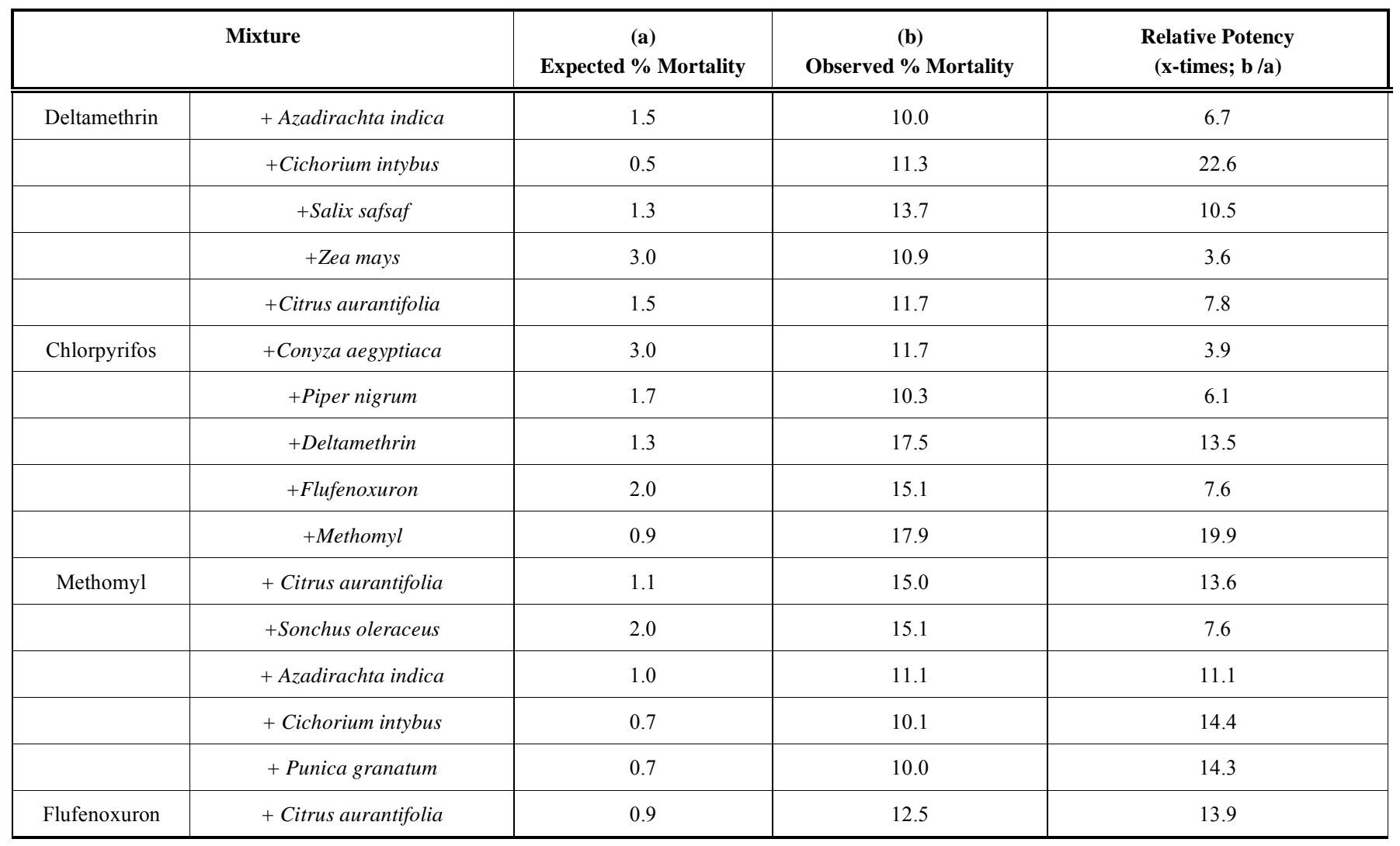

a) Expected \% mortality = summation of mortality (\%) from insects exposed to $\mathrm{LC}_{0}$ level of each toxicant in a paired combination as tested individually.

b) Observed \% mortality: refers to that of the mixture tested in the same experimental container at the $\mathrm{LC}_{0}$ level of each.

- Values of $\mathrm{LC}_{0}$ were obtained from the respective LC-P lines of the tested toxicants.

- Relative Potency $=\%$ observed mortality $/ \%$ expected mortality (b/a).

treated groups could be demonstrated. From the data shown in Table 6, it clears that all the tested toxicants caused severe shortage in the duration of larval and adult stages. For example, larval and adult stages in the treatment of Cichorium intybus accounted to 2.75 and 2.0 days, respectively, compared to 13.5 and 20.75 days in the control treatment. In the concerned treatment, cumulative mortalities were $23.1 \%$ (in larvae), $42.6 \%$ (in pupae), and 100.0\% (in adults). Complete adult mortalities were also observed in treatments of Conyza aegyptiaca, piper nigrum, and the insecticide flufenoxuron. The rest eleven toxicant treatments caused $100 \%$ pupal mortality and non adults were developed.

The effect of the tested toxicants on body weights of pupae was pronounced by significant decrease, compared with control, in some treatments. The lowest pupal weight was entitled to the treatment of Citrus aurantifolia $(6.1 \mathrm{mg} / \mathrm{pupa})$, compared to $8.0 \mathrm{mg} /$ pupa in control (Table 7). The average body weight of the adult in control treatment reached $3.2 \mathrm{mg}$, the treatments of Cichorium intybus, Conyza aegyptiaca, and flufenoxuron induced significant decrease accounting to 2.8, 2.7 and $2.6 \mathrm{mg} /$ adult, respectively. In contrast, Piper nigrum, Punica granatum and Sonchus oleraceus achieved highly significant increase in the adult body weight accounting to 6.3, 6.6 and $6.5 \mathrm{mg} /$ adult, respectively (Table 7).

Morphologically, there were different forms of pupal and adult abnormalities due to exposure of Musca domestica larvae to a number of the tested botanicals and insecticides. Fig. (1) demonstrates examples of abnormalities induced by certain treatments; such as: pupal-adult intermediate (pic. No. 3) observed in treatments of Punica granatum and Sonchus oleraceus; pupae of spherical body (pic. No. 4) observed in treatments of Salix safsaf and Zea mays; elongation of pupal body (pic. No. 5) in treatments of deltamethrin and methomyl. Developmental effects on the adult were seen as one-winged insects, small size, compressed body and abdomen elongation (pics. Nos. $6 \& 7$ ); especially in treatments of Cichorium intybus, Conyza aegyptiaca, Piper nigrum and flufenoxuron. Pictures numbers 1 and 2 show control pupa and adult, respectively for comparison purposes (Fig. 1).

\section{DISCUSSION}

It's common that housefly has been extensively utilized as a test organism to screen candidate insecticides, chemosterilants and insect growth regulators by scientists in public or private research institutions. In this investigation some plant extracts and some insecticides from four chemical groups (e.g., organophosphorus, pyrethroid, carbamate and growth regulators) were tested against larval stage of housefly (Musca domestica L.). The selected botanicals included five plant species from agricultural wastes (e.g., Opuntia vulgaris, Zea mays, Saccharum spp., Punica 
Table 6. Effect of Sub-lethal Concentrations of Tested Materials on the Development of $3^{\text {rd }}$ Larval Instars of Musca domestica

\begin{tabular}{|c|c|c|c|c|c|c|c|c|c|c|}
\hline \multirow[b]{2}{*}{$\begin{array}{l}\text { Tested material } \\
\text { (Plant extracts \& } \\
\text { Insecticides) }\end{array}$} & \multirow{2}{*}{$\begin{array}{c}\text { Initial } \\
\text { Number of } \\
\text { Used } \\
\text { Larvae }\end{array}$} & \multicolumn{3}{|c|}{ Larvae } & \multicolumn{3}{|c|}{ Pupae } & \multicolumn{3}{|c|}{ Adult } \\
\hline & & $\begin{array}{c}\text { Av. No. of } \\
\text { Tested Larvae }\end{array}$ & $\begin{array}{c}\text { Larval } \\
\text { Duration } \\
\text { (Day) }\end{array}$ & $\begin{array}{l}\text { Cumula-tive } \\
\text { Larval } \\
\text { Mortality \% }\end{array}$ & $\begin{array}{c}\text { Av. No. of Tested } \\
\text { Pupae }\end{array}$ & $\begin{array}{c}\text { Pupal } \\
\text { Duration } \\
\text { (day) }\end{array}$ & $\begin{array}{c}\text { Cumula-tive } \\
\text { Pupal } \\
\text { Morta-lity \% }\end{array}$ & $\begin{array}{c}\text { Av. No. of } \\
\text { Tested Adult }\end{array}$ & $\begin{array}{c}\text { Adult } \\
\text { Duration } \\
\text { (day) }\end{array}$ & $\begin{array}{c}\text { Cumu-lative } \\
\text { Adult } \\
\text { Morta-lity \% }\end{array}$ \\
\hline Control & $(120) 30 \times 4$ & (118) $29.5 \pm 0.29$ & $13.5 \pm 0.5$ & 1.7 & (116) $29.0 \pm 0.40$ & $4.5 \pm 0.29$ & 1.7 & (99) $24.8 \pm 0.25$ & $20.75 \pm 0.25$ & 0.0 \\
\hline Azadirachta indica & (120) $30 \times 4$ & (91) $22.8 \pm 0.25$ & $3.25 \pm 0.25 * *$ & 48.4 & (48) $12.0 \pm 0.41 * *$ & - & 100 & - & - & - \\
\hline Cichorium intybus & $(120) 30 \times 4$ & $(85) 21.3 \pm 0.25$ & $2.75 \pm 0.25 * *$ & 23.1 & (54) $13.5 \pm 0.5^{* *}$ & $2.25 \pm 0.25^{*}$ & 42.6 & (31) $2.0 \pm 0.0^{* *}$ & $2.0 \pm 0.0 * *$ & 100.0 \\
\hline Citrus aurantifolia & (120) $30 \times 4$ & (87) $21.8 \pm 0.63$ & $3.25 \pm 0.25 * *$ & 51.2 & (42) $10.5 \pm 0.29^{* *}$ & - & 100.0 & - & - & - \\
\hline Conyza aegyptiaca & $(120) 30 \times 4$ & (90) $22.5 \pm 0.29$ & $3.25 \pm 0.25 * *$ & 50.0 & (45) $11.25 \pm 0.75^{* *}$ & $1.5 \pm 0.29^{* *}$ & 48.9 & (23) $1.75 \pm 0.25^{* *}$ & $1.75 \pm 0.25^{* *}$ & 100.0 \\
\hline Eucalyptus globulus (fruits) & $(120) 30 \times 4$ & (89) $22.3 \pm 0.25$ & $3.75 \pm 0.25^{* *}$ & 48.3 & (46) $11.5 \pm 0.29 * *$ & - & 100.0 & - & - & - \\
\hline Eucalyptus globulus (leaves) & $(120) 30 \times 4$ & (87) $21.8 \pm 0.25$ & $3.0 \pm 0.0^{* *}$ & 47.1 & (46) $11.5 \pm 0.29^{* *}$ & - & 100.0 & - & - & - \\
\hline Piper nigrum & $(120) 30 \times 4$ & (90) $22.5 \pm 0.29$ & $2.25 \pm 0.25 * *$ & 52.2 & (43) $10.75 \pm 0.48^{* *}$ & $1.5 \pm 0.29 * *$ & 50.0 & (31) $1.75 \pm 0.25^{* *}$ & $1.75 \pm 0.25^{* *}$ & 100.0 \\
\hline Punica granatum & $(120) 30 \times 4$ & (90) $22.5 \pm 0.29$ & $3.25 \pm 0.25 * *$ & 53.0 & (37) $9.25 \pm 1.5^{* *}$ & - & 100.0 & - & - & - \\
\hline Salix safsaf & $(120) 30 \times 4$ & $(90) 22.5 \pm 0.25$ & $2.75 \pm 0.25^{* *}$ & 76.7 & (21) $5.25 \pm 0.25 * *$ & - & 100.0 & - & - & - \\
\hline Sonchus oleraceus & (120) $30 \times 4$ & (88) $22.0 \pm 0.0$ & $3.75 \pm 0.25 * *$ & 51.1 & (43) $10.75 \pm 0.25^{* *}$ & - & 100.0 & - & - & - \\
\hline Zea mays & $(120) 30 \times 4$ & (90) $22.5 \pm 0.29$ & $2.75 \pm 0.25 * *$ & 50.0 & (45) $11.25 \pm 0.75^{* *}$ & - & 100.0 & - & - & - \\
\hline Chlorpyrifos & $(120) 30 \times 4$ & (89) $22.3 \pm 0.25$ & $2.25 \pm 0.25 * *$ & 58.0 & (32) $8.0 \pm 0.41 * *$ & - & 100.0 & - & - & - \\
\hline Deltamethrin & (120) $30 \times 4$ & (90) $22.5 \pm 0.29$ & $2.0 \pm 0.0^{* *}$ & 58.9 & (37) $9.25 \pm 0.48^{* *}$ & - & 100.0 & - & - & - \\
\hline Flufenoxuron & $(120) 30 \times 4$ & $(90) 22.5 \pm 0.29$ & $3.5 \pm 0.29^{* *}$ & 46.7 & (48) $12.0 \pm 0.41 * *$ & $2.25 \pm 0.25^{*}$ & 47.9 & (25) $1.25 \pm 0.25^{* *}$ & $1.25 \pm 0.25^{* *}$ & 100.0 \\
\hline Methomyl & (120) $30 \times 4$ & (90) $22.5 \pm 0.29$ & $2.25 \pm 0.25 * *$ & 60.0 & (36) $9.0 \pm 0.41 * *$ & - & 100.0 & - & - & - \\
\hline
\end{tabular}

N.B.: The larvae were exposed to the tested materials at $\mathrm{LC}_{25}$ levels for $24 \mathrm{~h}$, and then subjected to the subsequent examinations.

The data are expressed as mean \pm SE. ; - : No results.

*Significant at $\mathrm{P}=(0.001-0.05) * *$ Highly significant at $\mathrm{P} \leq 0.001$ Insignificant at $\mathrm{P} \geq 0.05$.

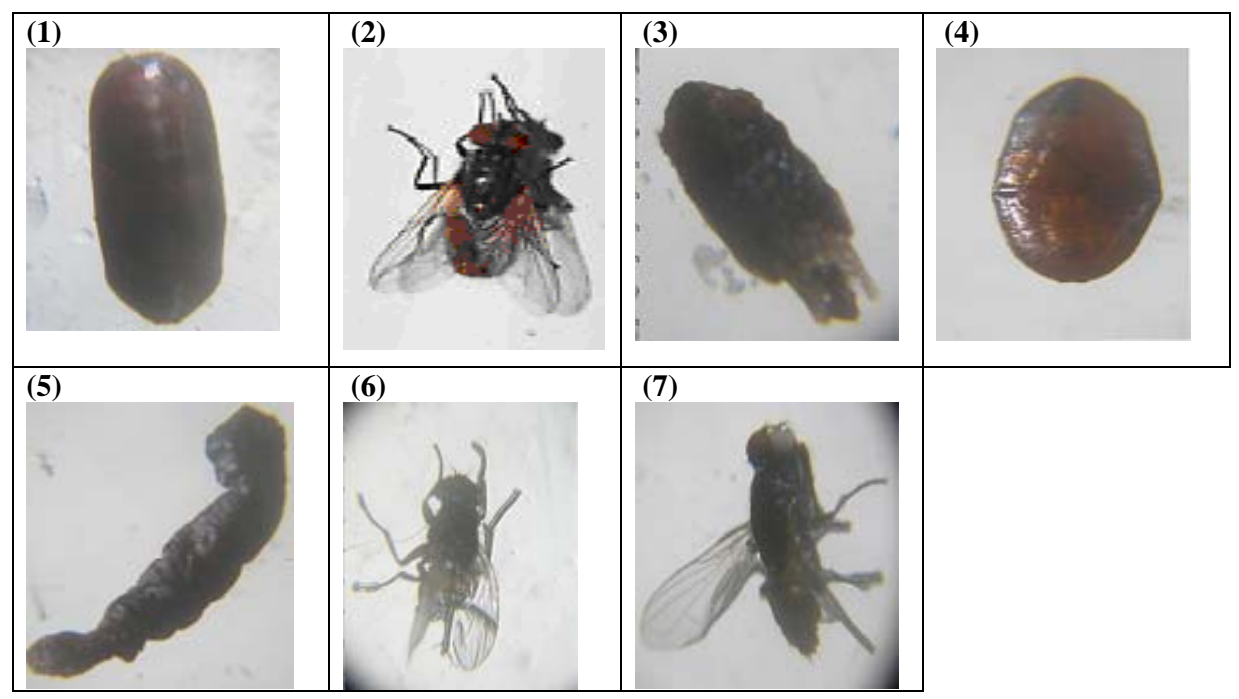

Fig. (1). Different forms of pupae and adult abnormalities resulted from exposing Musca domestica larvae to sublethal concentrations of tested plant extracts and insecticides: (1): normal (control) pupae; (2): normal (control) adult; (3): pupal-adult intermediate; (4): pupae of spherical body; (5): elongation of pupal body; (6 \& 7): one-winged insect of small size, compressed body and abdomen elongation.

granatum, Citrus aurantifolia), three weeds (e.g., Cichorium intybus, Conyza aegyptiaca, Sonchus oleraceus), three ornamental trees (e.g., Azadirachta indica, Eucalyptus globulus, Salix safsaf), and one agricultural crop (e.g., Piper nigrum). Among the selected plants, two candidates (e.g., A. indica and $P$. nigrum) are often considered the most promising and bioactive [24] and thus could be used for comparative purposes with the other tested plants.

Most extracts tested here have showed potential insecticidal activity. The results of toxicity may indicate possible 
Table 7. Body Weight of Musca domestica Pupae and Adults Exposed During Larval Stage to Sublethal Concentrations of Tested Plant Extracts and Insecticides

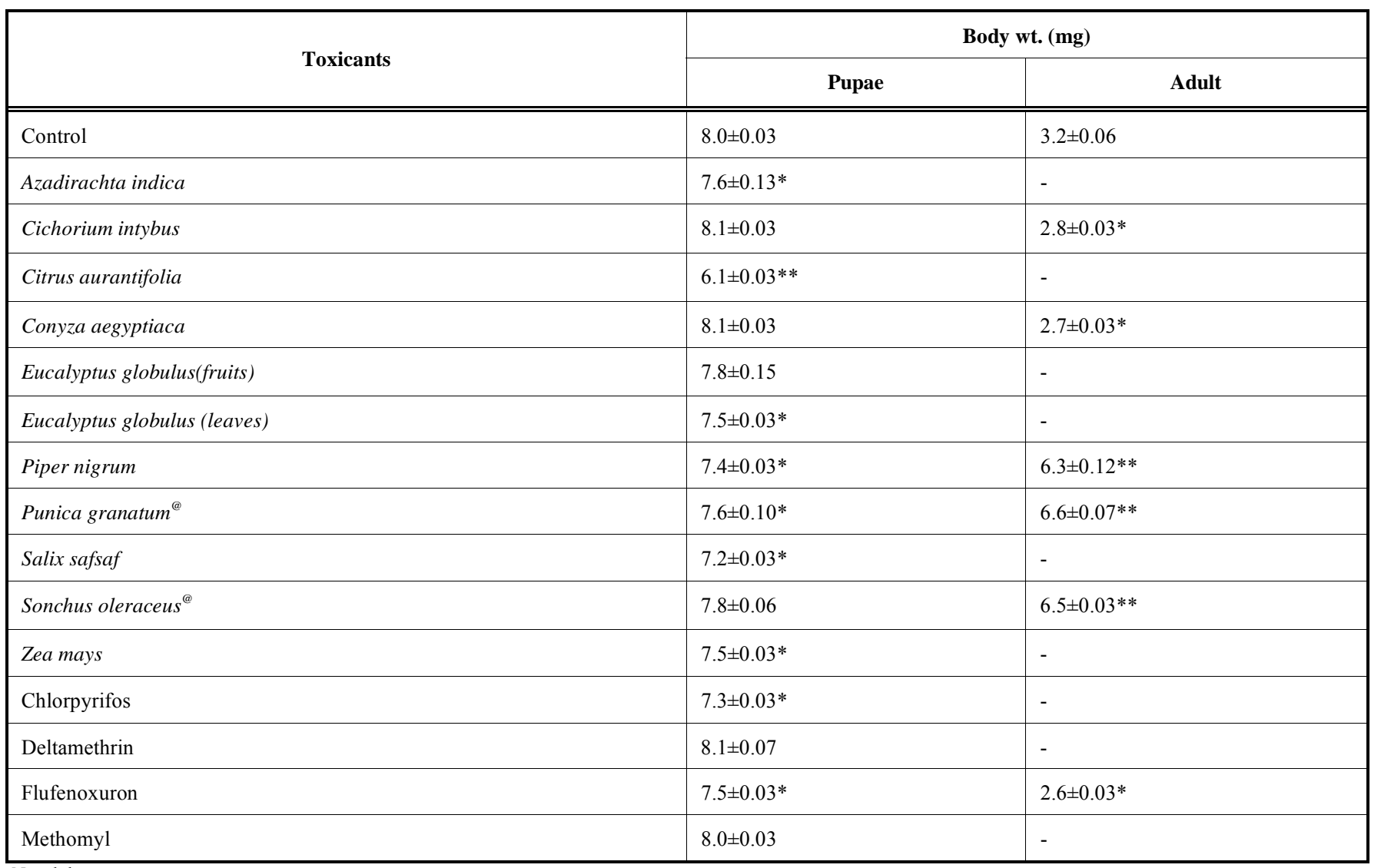

-No adult emergence.

Statistical difference from the corresponding control values: *significant at $(\mathrm{p} \leq 0.05)$; ** highly significant at $(\mathrm{p} \leq 0.01)$.

${ }^{\circledR}$ pupal-adult intermediate (refer to Fig. 1).

contact neurotoxic action of the active constituents of the plant species that is mainly related to the acetycholinesterase and octopaminergic levels $[25,26]$ or the active constituents may transform the alcohol present into the insect body into the corresponding esters [27]. The volatile extracts of peel Citrus aurantifolia (lime) was reported to have insecticidal activity against mosquito, cockroach and housefly, when used as spray in rooms containing the tested insects [28]. The present investigation introduces additional data on its potency against $M$. domestica larvae. Ethanolic extract of $A$. indica showed $\mathrm{LC}_{50}$ accounting to $76.9 \mathrm{ppm}$; ranking it as equitoxic as Conyza aegyptiaca $\left(\mathrm{LC}_{50}=77.0 \mathrm{ppm}\right)$ and coming second, over the twelve plant extracts, after Piper nigrum extract $\left(\mathrm{LC}_{50}=50.1 \mathrm{ppm}\right)$ (Table 2). These findings spot light to the plant Conyza aegyptiaca as a promising candidate bioinsecticide.

Eucalyptol, one of the active constituents in Eucalyptus globulus, has been documented to be very toxic to male housefly at $\mathrm{LD}_{50}$ of $118 \mu \mathrm{g} / \mathrm{fly}$ [14]. Both extracts of $E$. globulus (fruits and leaves) showed "moderate toxicity" to the $M$. domestica larvae (Table 2), however, leaf extract $\left(\mathrm{LC}_{50}=115.0 \mathrm{ppm}\right)$ was more potent than fruit extract $\left(\mathrm{LC}_{50}\right.$ $=118.3 \mathrm{ppm})$. This may refer to the concentration of the active conctituent(s) in the two plant parts. It has been long recognized that the pesticidal activity of Eucalyptus refers to the compound 1,8-cineole which is abundantly present in the essential oil $[29,30]$. Previous studies reported high toxicity of E. globulus extracts to pupae of Musca domestica [16] and other insects.

Most studies on the synergistic, antagonistic and additive toxic effects of binary mixtures involving phytochemicals have been conducted on agricultural pests rather than pests of medical importance. In an attempt to explain synergistic activity involving phytochemicals, Thangam and Kathiresan [23], in their studies on mosquitoes, surmised that synergism might be due to phytochemicals inhibiting a mosquito larva's ability to use detoxifying enzymes against synthetic chemicals. Identifying these synergist compounds within mixtures may lead to the development of more effective biocides as well as the use of smaller amounts of synthetic insecticides in the mixture to achieve satisfactory levels of efficacy. Indeed, joint action may well prolong the usefulness of synthetic insecticides that will eventually be unusable due to resistance [31]. Our earlier studies on Culex pipiens larvae with Nigella sativa seed extracts [32], volatile oil of Thymus capitatus [33], citrus peel oils [34], and different ethanolic plant extracts against larvae and adult stages of Anopheles pharoensis [35] have shown potentiating toxicity when mixed these botanicals with certain insecticides in pairs of combinations. The present results on $M$. domestica larvae 
with plant extracts + insecticides agree with these findings as all the mixtures induced potentiating effects against the larvae of the housefly (Table 3). Also, combining insecticides (at $\mathrm{LC}_{0}$ ) with plant extracts $\left(\right.$ at $\mathrm{LC}_{50}$ ) resulted in synergistic effects (Table 4). Interestingly, non-lethal concentrations from both toxicants when mixed together induced potency (in terms of larval mortality) higher than the sum mortality of the two toxicants in a given mixture (Table 5).

The pyrethroid insecticide deltamethrin when combined with any of the tested plant extracts induced synergistic effects against the housefly larvae (Table 4). These results coincide with those reported on cypermethrin combined with leaf and seed extracts of neem (Azadirachta indica) to four strains of the adult red flour beetle Tribolium castaneum (Herbst). Pyrethroids have disruptive effects on a variety of arthropod sensory preparations [36].

Some plants harbor insect juvenile and molting hormones or anti hormonal activity $[37,38]$ which could be useful as an agent for achieving this strategy. The insect growth regulators are advantageous because they do not persist long in the environment due to their rapid biodegradation and low toxicity. The development of resistance to these substances has not yet been proved [39-41] and their effectiveness in practical applications has been considered sufficient. Thus, in the absence of highly toxic natural botanical compounds, the growth or emergence inhibiting activity of a botanical phytochemical may be essential to its uptake by the insecticide industry [42].

The literature offers much information about developmental effects of a vast number of plant extracts and their phytochemical constituents against housefly. For examples, the seed of Peganum harmala and leaves of Acalypha indica, Carica papaya, Santalum album and Calotropis gigantica were screened for biological activity against the larval-pupal and pupal-adult transformation stages of the housefly, Musca domestica. All the plant materials screened, except Carica papaya, prolonged the life of larvae, hindered larval-pupal transformation and reduced pupal weight considerably. Eclosion of the pupae was also hindered to varying extents by all the plants tested. A compounded diet of housefly containing these plant materials no doubt contains desirable primary or secondary principles which may have developed from the interactions of the components of the diet. These principles elicit biological activities in respect of larval/pupal transformation and pupal eclosion hindrances and they could be useful in the formulation of a desirable housefly management strategy [43]. Seed extracts of Griffonia simplicifolia evoked a very strong regulatory effect against the second larval instars of the housefly. Seed extracts also induced some morphological abnormalities in larvae, pupae and adult houseflies. The abnormalities included retardation of development of larvae, failure to emerge from the pupal case, and incomplete development of wings in adults that died $12 \mathrm{~h}$ after emergence [44]. This may suggest the presence of high juvenile hormone levels in the larvae or else due to chemical compounds in the plants preventing normal pupation and generating adult deformities [45].

Specifically, Neem and its products have received considerable attention of scientists for its potential insecticidal activity against many different insects including Dipterans.
Zebitz [46] reported the anti-ecdysteroid activity of neem seed kernel extract in resulting in growth inhibition and prolonged developmental period. The benefit of elongation is that housefly larvae numbers are reduced due to longer life cycle and would decrease the vectorial capacity of houseflies. Sexena et al., [47] reported developmental abnormalities in larvae of Cnaphalocrocis medinalis after treatment with $50 \%$ neem oil. They observed that moths were unable to emerge from their pupal cases, as in the present study in which adult Musca domestica did not completely emerge from puparium. Therefore, the results of Sexena et al., [47] is comparable with our results. Jahan et al., [48] reported that a number of $M$. domestica adults exposed to some neem products failed to come out from the puparium. Comparable abnormalities have been recorded for $M$. domestica after treatment of the third larval instars with sesame, Nigella, onion, diflubenzuron, and pyriproxfen [49]. The abnormalities could be attributed to the metamorphosis inhibiting effect of plant oils, as a result of the disturbance of hormonal control, suggesting a type of insect growth regulating activity [50]. The presence of larviform puparia could result from the failure of larvae to contract to the pupal form, as a result of muscle paralysis, but their ability to acquire melanization of the pupal cuticle, because of the continuation of the enzymatic process of tanning [50]. The failure of adult emergence could occur as a result of a combination of two or more of the following factors: unsaturated fatty acids, which accelerate the process of melanization and hardening of the larvae (thus adults are unable to extricate themselves from the pupal excuviae); insufficient pressure in the ptilinum; and hardening of the opercular suture [50].

The data presented in Table 6 indicate that the average number of pupae resulted from treatment of $3^{\text {rd }}$ instars larvae of $M$. domestica with sublethal concentrations of the tested toxicants was highly decreased compared to the corresponding number in control treatment. Moreover, there was a severe decrease in the percentage of adult emergence of $M$. domestica. These results are in a good agreement with those obtained on the same insect by several IGRs; such as: methoprene [51, 52]; BAY SIR 8514 [53]; cyromazine [54]; Pyriproxyfen [55, 56]; fenoxycarb [57]; RH-5849 [58]; and hexaflumuron [56]. All of these previously tested compounds are known as IGRs like the compound, flufenoxuron, which tested in the present investigation and showed more than $50 \%$ decline in pupation (Table 6). The decrease in the percentage of adult emergence could be due to the fact that IGRs block the maturation of imaginal discs which are the primordial of many adult integumentary structures in endopterygote insects or due to deformation of adult chitin [59].

On the other hand, the tested toxicants induced reduction in the pupal weight. Compared to control result, the reduction was insignificant with Cichorium intybus, Conyza aegyptiaca, Eucalyptus globulus (fruits) and Sonchus oleraceus, as well as, the insecticides deltamethrin and methomyl (Table 7). Body weight recorded significant decrease $(\mathrm{p} \leq 0.05)$ with Azadirachta indica, Eucalyptus globulus (leaves), Piper nigrum, Punica granatum, Salix safsaf, Zea mays, chlorpyrifos and flufenoxuron. However, a highly significant difference $(\mathrm{p} \leq 0.01)$ was observed with Citrus aurantifolia. Abdel-Aal [60] attributed such decrease of pupal weight of $M$. domestica to the decrease in total water 
content or decreased intensity of protein biosynthesis. Also, it may be due to the lack of proper sclerotization of the newly formed puparium, or evaporation of body fluids leading to decreased pupal weight.

\section{CONCLUSION}

The results of the present investigation reveal the broadspectrum toxic properties of the tested botanical extracts against the larval stage of Musca domestica. The interesting result is the developmental efficacy of the tested materials and their synergistic action with conventional chemical pesticides. Such findings could be exploited for integrated pest management (IPM) programs. However, further studies need to be conducted to evaluate the mode of action and costefficacy of these materials under practical field conditions.

\section{ACKNOWLEDGEMENT}

None declared.

\section{CONFLICT OF INTEREST}

The authors declared no conflict of interest.

\section{REFERENCES}

[1] Khan MF, Ahmed SM. Toxicity of crude neem leaf extract against houseflies Musca domestica adult as compared with DDVP, dichlorvos. Turk J Zool 2000a; 24: 219-23.

[2] Greenberg B. Flies and disease. Biology and disease transmission. Princeton University Press: New Jersey 1973; Vol. II.

[3] El Boushy AR. Housefly pupae as poultry manure converters for animal feed: A review. Bioresour Technol 1991; 38: pp. 45-9.

[4] Jiang SJ. Chinese Pharmaceutical Insects (in Chinese). Chinese Forestry Publishing House: Beijing, China 1999; pp. 266-8.

[5] Hou L, Shi Y, Zhai P, Le G. Antibacterial activity and in vitro antitumor activity of the extract of the larvae of the housefly (Musca domestica). J Ethnopharmacol 2007; 111: 227-31.

[6] Feng X, Cheng G, Chen S-Y, Yang H, Wen Huang W. Evaluation of the burn healing properties of oil extraction from housefly larva in mice. J Ethnopharmacol 2010; 130: 586-92.

[7] NRC (National Research Council). The future role of pesticides in U.S. agriculture. Committee on the future role of pesticides in U.S. agriculture, board on agriculture and natural resources and board on environmental studies and toxicology, Commission on Life Sciences. Washington DC: National Academy of Sciences 2000

[8] Khan MF, Ahmed SM. Toxicity of neem fruit extract and neem seed oil against Oxycarenus (Heteroptera) of cotton crop. Acta Biol Caracoviensia Zool 2000b; 42: 17-21.

[9] Azmi MA, Naqvi SN, Azmi MA, Aslam M. Effect of pesticide residues on health and different enzyme levels in the blood of farm workers from Gadap, Karachi (an enzyme pesticide relationship study). Chemosphere 2006; 64: 1739-44.

[10] Belmain SR, Neal GE, Ray D, Golob, P. Insecticidal and vertebrate toxicity associated with ethnobotanicals used as postharvest protectants in Ghana. Food Chem Toxicol 2001; 39: 287-91.

[11] Shalaby AA, Allam KA, Mostafa AA, Fahmy SM Insecticidal properties of citrus oils against Culex pipiens and Musca domestica. J Egypt Soc Parasitol 1998; 28; 595-606.

[12] Liao SC. Mortality and repellency effects of essential oils from citrus against the housefly and German cockroach. Zhonghua Kunchong 1999; 19: 153-60.

[13] Morsy TA, Rahem MM, Allam KA. Control of Musca domestica third instar larvae by the latex of Calotropis procera (Family: Asclepiadaceae). J Egypt Soc Parasitol 2001; 31: 107-10.

[14] Sukontason KL, Boonchu N, Sukontason K, Choochote W. Effects of eucalyptol on housefly (Diptera: Muscidae) and blow fly (Diptera: Calliphoridae). Rev Inst Med Trop Soc Paulo 2004; 46(2): 97-101.
[15] Abdel Halim AS, Morsy TA. Efficacy of Trigonella foenumgraecum (fenugreek) on third stage larvae and adult fecundity of Musca domestica. J Egypt Soc Parasitol 2006; 36: 329-34.

[16] Abdel Halim AS, Morsy TA. The insecticidal activity of Eucalyptus globulus oil on the development of Musca domestica third stage larvae. J Egypt Soc Parasitol 2005; 35: 631-6.

[17] Sawicki RM. Some general considerations on housefly rearing techniques. World Health Organ 1964; 31: 535-37.

[18] Freedman B, Nowak LJ, Kwalek WF, Berry EC, Gutnrie WD. A bioassay for plant derived pest control agents using the European corn borer. J Econ Entomol 1979; 72: 541-5.

[19] Wright JW. The who Programme for the evaluation and testing of new insecticides. Bull World Health Organ 1971; 44: 11-2.

[20] Abbott WS. A method of computing the effectiveness of insecticide. J Econ Entomol 1925; 18: 265-7.

[21] Finney DJ. Probit Analysis. 2nd ed. Cambridge University Press: Cambridge 1971

[22] Sun YP, Johnson ER. Analysis of joint action of insecticides against house flies. J Econ Entomol 1960; 53, 887-92.

[23] Thangam TS, Kathiresan K. Synergistic effects of insecticides with plant extracts on mosquito larvae. Trop Biomed 1990; 7(2): 135-7.

[24] Grainge M, Ahmed S. Handbok of plants and pest control properties. New York: John Wiley and Sons 1998.

[25] Isman MB. Plant essential oils for pest and disease management Crop Prot 2000; 19: 603-8.

[26] Kostyukovsky M, Rafaeli A, Gileadi CD, Shaaya NE. Activation of octopaminergic receptors by essential oil constituents isolated from aromatic plants possible mode of action against insect pests. Pest Manage Sci 2002; 58: 1101-6.

[27] Tsao R, Coats JR. Starting from natural to make a better insecticides. Chentech 1995; $25: 23-8$.

[28] Ezeonu FC, Chidume GI, Udedi SC. Insecticidal properties of volatile extracts of orange peels. Bioresour Technol 2001; 76: 2734.

[29] Duke JA. Dr. Duke's Phytochemical and Ethnobotanical databases. 2004. Available online at http://www.ars-grin.gov/duke/ [accessed on 9 June, 2008].

[30] Yang YC, Choi HC, Choi WS, Clark JM, Ahn YJ. Ovicidal and adulticidal activity of Eucalyptus globulus leaf oil terpenoids against pediculus humanus capitis (Anoplura: Pediculidae). J Agric Food Chem 2004; 52: 2507-11.

[31] Shaalan EAS, Canyon DV, Younes MWF, Abdel- Wahab H, Mansour AH. A review of botanical phytochemicals with mosquitocidal potential. Environ Int 2005; 31:1149-66.

[32] Mansour SA, Messeha SS, Hamed SM. Botanical biocides 5. mosquitocidal activity of certain nigella sativa constituents. J Union Arab Biol 1998; 10(A): 45-63.

[33] Mansour SA, Messeha SS, El-Gengaihi SE. Botanical biocides. 4. mosquitocidal activity of certain thymus capitatus constituents. J Nat Toxins 2000; 9; 49-62.

[34] Mansour SA, El-Sharkawy AZ, Ali AR. Mosqitocidal activity of citrus peel oils with respect to their limonene content. Egypt J Nat Toxic 2004; 1: 111-34

[35] Mansour SA, Bakr RF, Hamouda LS, Mohamed RI. Toxic and synergistic properties of several botanical extracts against larval and adult stages of the mosquito, anopheles pharoensis. Biopestic Int 2010; 6(2): 129-45.

[36] Khalequzzaman M, Khanom M. Effects of cypermethrin alone and in combination with leaf and seed extracts of neem against adult Tribolium castaneum (Herbst). Univ J zool: Rajshahi Univ 2006; 25: 45-9.

[37] Morgan ED. Strategy in the isolation of insect control substrates from plants. Proc $1^{\text {st }}$ Int Neem Conf Rottach-Egern. 1980; pp 43 52, Germany.

[38] Schmutterer H. Properties and potential of natural pesticides from the neem tree Azadirachta indica. Ann Rev Entomol 1990; 35: 271-97.

[39] Farkas R, Pap L. Monitoring of susceptibility to cyromazine and diflubenzuron in house fly (Musca domestica L.) population in Hungary. Parasit Hung 1991; 24: 99-107.

[40] Keiding J, Jespersden JB, EL-Khodary AS. Resistance risk assessment of two insect development inhibitors, diflubenzuron and cyromazin, for control of the house fly Musca domestica. Part I.: Larvicidal tests with insecticideresistant laboratory and Danish field populations. Pestic Sci 1991; 32: 187-206. 
[41] Sheppard DC, Gaydon DM, Miller RW. Resistance in house flies (Diptera: Muscidae) selected with $5.0 \mathrm{ppm}$ feed-though cyromazine. J Agric Entomol 1992; 9: 257-60.

[42] Kocisova A, Venglovsky J, Para L, Petrovsky M. Control of the houseflies (Musca domestica) using the insect growth regulator diflubenzuron. Czech J Anim Sci 2000; 45: 475-80.

[43] Ande AT. Biological activities of some plant materials against the housefly - Musca domestica. NISEB J 2001; 1(4): 293-6.

[44] Bisseleua HBD, Gbewonyo SWK, Obeng- Ofori D. Toxicity, growth regulatory and repellent activities of medicinal plant extracts on Musca domestica L. (Diptera: Muscidea). Afr J Biotechnol 2008; 7: 4635-42.

[45] Crook TC, Flatt T, Smiseth PT. Hormonal modulation of larval begging and growth in the burying beetle Nicrophorus vespilloides. Anim Behav 2008; 75: 71-7.

[46] Zebitz CPW. Effects of some crude and azadirachtin-enriched neem (Azadirachta indica) seed kernel extracts on larvae of Aedes aegypti. Aust J Entomol 1984; 39: 208-11.

[47] Sexena RC, Liquido NJ, Justo HD. Neem seed oil, a potential antifeedant for the control of the rice brown plant hopper, Nilaparvata lugens. Proc 1st Int Neem Conf (Rottach- Egern, 1980) 1981: pp. 171- 87, germany.

[48] Jahan M, Ahmad I, Naqvi SNH. Toxic teratogenic effects of Juliflorine and Morgosan-OTM on the Musca domestica L. larvae. Proc Pak Congr Zool 1990; 10: 293-9.

[49] Khater HF. Biocontrol of some insects. Ph.D. Thesis, Zagazig University: Benha 2003: pp. 151.

[50] Hussien KT. Effect of some plant extracts in the control of a nonbiting muscoid fly. Ph. D. Thesis. Cairo University, Cairo 1995: pp. 237.

[51] Breeden GC, Turner EC, Beane WL, Miller RW, Pickens LC. The effect of methoprene as a feed additive on house fly emergence in poultry houses. Poult Sci 1981; 60: 556-62.
[52] Vignau ML, Romero JR, Baldo A, Risso MA, Silvestrini MP. The effect of methoprene on Musca domestica: laboratory Bioossays. Analecta Vet 2003; 23(2): 11-4.

[53] Weaver JE, Begley JW. Laboratory evaluation of BAY SIR 8514 against the house fly (Diptera: Muscidae) effects on immature stages and adult sterility. J Econ Entomol 1982; 75(4): 657-61.

[54] Awad TI, Mulla MS. Morphogenetic and histopathological effects induced by the insect growth regulator cyromazine in Musca domcstica. J Med Entomol 1984; 21 (4): 419 - 26

[55] Hatakoshi M, Kawada H, Nishida S, Kisida H, Nakayama I. Laboratory evaluation of 2-[1-methyl-2-(4-phenoxyphenoxy)-ethoxy] pyridine against larvae of mosquitoes and house fly. Japanese J Sanit Zool 1987; 38(4): 271-4.

[56] Assar AA, Abo-Shaeshae AA. Effect of two insect growth regulators, methoxyfenozide and pyriproxyfen on the housefly, Musca domestica vicina (Diptera: Muscidae). J Egypt Ger Soc Zool 2004; 44(E): 19-42.

[57] Fouda MA, Ghoneim KS, Bream AS. Biological activity of fenoxycarb (R013-5223) against house fly, Musca domestica. J Egypt Ger Soc Zool 1991; 5: 277-88.

[58] Ghoneim KS, Fouda MA, Bream AS. Effectiveness of the nonsteroidal ecdysone mimic, RH-5849 for the control of Musca domestica vicina. J Egypt Soc Parasitol 1991; 21:723-33.

[59] Schineidermann HA. Insect hormone and insect control. In: Mean J, Beroza M, Eds. Insect juvenile hormone, Chemistry and action. Academic presses: New York, London 1972; pp. 3-27.

[60] Abdel-Aal AE. Biological, histological and physiological effects of some insect growth regulators on the greasy cutworm, Agrotis ipsilon (Lepidoptera: Noctuidae). M.Sc. Thesis 1996; Faculty of Science, Cairo University Egypt. 